\title{
Impact of Renewable Technology on Palm Fruit Fibre: Strategy for Climate Change and Adaptation
}

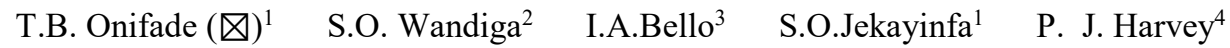 \\ 1.Department of Agricultural Engineering, LadokeAkintolaUniversity of Technology,Ogbomoso, Nigeria \\ 2.Institute for Climate Change and Adaptation, University of Nairobi, Nairobi, Kenya \\ 3.Department of Pure and Applied Chemistry, LadokeAkintolaUniversity of Technology,Ogbomoso, Nigeria \\ 4.Faculty of Engr and Science, University of Greenwich Central Avenue, Kent, United Kingdom
}

\begin{abstract}
This study aims to explore low temperature and pressure to extract the lignocellulosic content of palm fruit fibre and pyrolyse it for energy (bio-oil) and chemical feedstock productions as alternative technology to improper disposal causing environmental pollution as strategies for climate change and adaptation.Burning of refuse and agricultural residue releases harmful gases or carbon emission to the climate which cause global warming. Renewable technology can therefore be introduced to utilize agricultural residues to produce energy and chemical feedstock. Vacuum pyrolysis of the lignocellulosic material prepared from palm fruit fibre was performed by considering pyrolysis temperature of $200,250,300,350$ and $400{ }^{\circ} \mathrm{C}$ and biomass particle size of $0.25,0.30,0.42$ and $0.55 \mathrm{~mm}$. The bio-oil produced at different process parameters was then characterized by gas chromatographymass spectrometry (GC-MS) and ultimate analysis. The response was efficiently used for modeling and optimization of the process parameters. The results showed that experimented and predicted data are in reasonable agreement with the values of coefficient of determination, $\mathrm{R}^{2}(0.8098)$ and Adj. $\mathrm{R}^{2}(0.700)$. It was found that the optimal conditions for pyrolytic product were temperature $300^{\circ} \mathrm{C}$, biomass particle size $0.55 \mathrm{~mm}$ and retention time between 14 and $18 \mathrm{~min}$. Temperature and particle size had effect on the yielded gaseous products, liquid and char materials. And various chemical compounds were produced at different process parameters. The contribution of renewable technology framework is a process of educating for climate stewardship, at this stage of practical and theoretical. It is good approach of converting residues to useful products as one of the ways of solving climate change problem with the relevant stakeholders that its true potential can be assessed. Educating the public for climate stewardship will be more effective if it adopts anapproach which seeks a co-production of knowledge. Clean environment with less global warming will be attained. This agricultural residue can be recommended for bio-fuel, bio-gas and used as chemical feedstock for industrial purpose. The char can also be used to increase soil organic components. These benefits can therefore be used for policy making on residue disposal and as strategy for climate change and adaptation or mitigation in Nigeria and other African countries.
\end{abstract}

Keywords: Palm fruit fibre. Pyrolysis.Renewableenergy.Lignocellulose.Climate change

DOI: $10.7176 /$ ISDE/10-3-02

Publication date:March $31^{\text {st }} 2019$

\section{Introduction: Climate Change and Energy}

The world's climate and weather conditions are changing. Global temperatures are rising and causing more extreme weather disasters, like flooding and heat waves (UKEA, 2015). 'Adaptation' means changing the way of doing things to prepare for the potential impacts of climate change.

This implies that human will be better protected against consequences like flooding and other weather events (UKEA, 2015). Weather variability and the effect on society varies across the country, the effect of climate change on our economy, infrastructure, society and environment also vary from place to place. These help to make strategic plans for and adapt to climate changes (UKEA, 2015). It will also result to better preparation for new opportunities, like the chance to grow different crops and innovations on renewable technologies to convert wastes to energy, health risks during heatwaves can be reduced through effective planning and responses by health and social services, and poor rainfall or drought which causes low crop productivity can be improved by new system of irrigation. Although, FAO (2001) reported that a long-term change in weather had occurred in the semiarid and sub-humid zones of West Africa. And it appears that little or nothing can be done to improve variability in weather since most of its causes are natural.

A slightly change in temperature at the right moment can cause outbreaks of epidemic diseases or insect pests, which can destroy entire landscapes, forest or farmlands as shown in Fig. 1. Everything in nature is related, changes in one area trigger changes in other areas(Osagie, 2002; Adejuwon and Odekunle, 2006). For example, the immediate survival of many coastal areas, population, forests and wildlife may now depend on our ability to study, understand and share the small changes that are observed in the environments and ecosystems around man. The current talk about weather variability has been correlated with the activities of man which have in turn generated micro weather variation, pollution of environment by forest fuels burnt daily from industries and automobiles all of which generate heat, there by altering the heat balance as seen in Fig. 2 (Osagie, 2002; Adejuwon and Odekunle, 


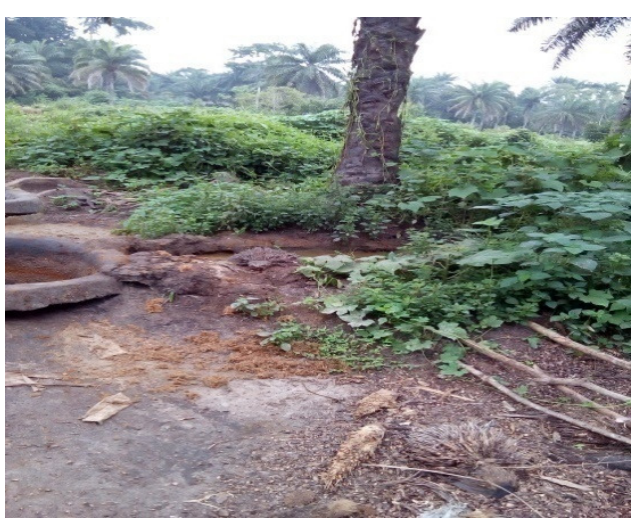

Fig. 1: Land pollution

\section{(Source: Research study site)}

Climate change is caused by the rate at which energy is received from the sun and the rate at which it is lost to space determines the equilibrium temperature and climate of Earth. This energy is distributed around the globe by winds, ocean currents, and other mechanisms to affect the climates of different regions (USEPA, 2006). Consequently, the use of conventional drying for agricultural materials must be adapted to revolutionize the climate to reduce the rate of energy received from the sun and greenhouse gas emissions as reported by Onifadeand Jekayinfa(2015). Conventional (air) drying is mostly used for dehydration operation in food and chemical industry, because drying occurs under controllable conditions and partially depend on climatic conditions and also reduce drying time (Onifade and Jekayinfa2015).

Climate change can be most generally defined as a change in the statistical properties of the climate system when considered over long periods of time, regardless of cause (GCC2001). Accordingly, fluctuations over periods shorter than a few decades refer specifically to climate change caused by human activity, as opposed to changes in climate that may have resulted as part of Earth's natural processes (NASA2011). In this situation, especially in the context of environmental policy, the term climate change has become synonymous with anthropogenicglobal warming. Within scientific journals, global warming is stated as surface temperature increases while climate change includes global warming and everything else that will be affected by increasing greenhouse gas levels, (UNFCCC 1994). Climate change also refers to a change of climate which is directly or indirectly attributed to human activity that affects the composition of the global atmosphere and which is in addition to natural climate variability observed over comparable time periods.

The root cause of energy situation is that in the recent years, while there has been no limit on growth in energy demand, the production of energy from the existing sources has come under increasing mounting pressure. It seems probably therefore, that the shortage of fuel (energy) supplies is an actual fact of life and the fossil fuel supplies in our planet may not last forever (Bello et al.2009). There is energy crisis in our hand, henceforth source of energy supply is far below energy consumption. However, there are various renewable energy sources which could reduce the demand on fossils fuels. The renewable technology saves time and it is usually more environmentally friendly, especially on air emissions (Schroeder2009). There is great potential in the utilization of renewable biomass for energy and chemicals production to develop human life prosperity to address the crisis of energy security and sustainable economics in the world (Schroeder2009; Ren et al.2013).

Nigeria as a country is blessed with abundant agricultural resources; the materials that are left behind are called agricultural wastes or residues (Onwualu2010). Agriculture is practiced almost in every nation of the world and large volume of crop residues that remains after harvest of crops is produced. Some of the agricultural residues generated are palm fruit fibre, physic nut shell, palm kernel shell, palm tree bark, maize cob, maize husks, maize stalk, cassava stalk, guinea corn stalk, cassava peels, millet stalks, plantain peels, groundnut husks, oil palm empty bunches, palm kernel cake and cowpea shells (Jekayinfa and Scholz2007). Fortunately, in Nigeria large quantities of wastes are generated annually but unfortunately, these residues are not properly utilized as they are left to rot away or decompose (Jekayinfa and Omisakin2005). A large percentage is dumped at refuse dump or land fill sites or burnt which has environmental implications (USEPA 2006). It is unbelievable that biomass in general, can displace most of other fuel or source of energy. This does not distract, however, from the fact that biomass fuel have a very significant part to play in meeting our energy needs. It is a unique part with the realization of the finite 
limitation of the fossil resources, a sense of urgency has developed in the exploration of alternative energy and feedstock sources.

Palm fruit fibre has great potentials to be used as biomass to develop renewable energy.It is unbelievable that biomass in general, can displace most of other fuelor source of energy. This does not distract, however, from the fact that biomass fuel has a very significant part to play in meeting our energy needs. It is a unique part with the realization of the finite limitation of the fossil resources, a sense of urgency has developed in the exploration of alternative energy and feedstock sources. The black solid product obtained after pyrolysis process is known as char. This has potential soil-quality benefits which include an increase in organic matter and soil carbon. Higher concentrations of carbon in the soil reduce crusting, rapid soil surface drying and compaction, and improve soil structure, water infiltration, water-holding capacity and microbial activity. Decades of crop production have depleted organic matter and soil carbon from many fields in western Nebraska, according to Hergert (UNL, 2016). As abundant renewable resources, cellulosic material is being recognized as a possible supplement for long term requirement (Bello et al.2009). And biofuel sources such as materials like irrigated grasses would grow well on soil containing char (UNL, 2016). The main benefit of converting waste to energy is to improve the economy of the nation and it also has beneficial environmental implications (Onwualu, 2010).

Pyrolysis is defined as the thermo-chemical conversion of biomass to char, bio-oil and gas, in the absenceof oxygen and other reactants (Balatet al.2009; Goyal et al.2006). It always occurs before combustionand gasification where complete or partial oxidation is allowed to proceed. Pyrolysis is a complex non-equilibriumprocess where the biomass undergoes multistage decomposition resulting in large changes inspecific volume (Tsai et al., 2006). The reaction rate, order and product yields depend on parameters such as temperature,heating rate, pre-treatment, catalytic effects etc. (Bridgwateret al.1996 and 2002). The reactionmechanism can be approximated by combining the yields from the three lignocellulosic compounds,despite synergetic effects. Therefore the study of individual components forms the basis of the expectedreaction pathways (Van de Veldenet al.2010). Cellulose is the focus of much research because it is thedominant lignocellulosic compound, and therefore cellulose decomposition is best understood. However, if the gases and oil coming from the process are then burnt, this may also generate emissions. Also, this renewable method is quicker to build and the energy produced may be eligible for more renewable obligation certificates than incineration, increasing the potential from any power generated. Any fuel produced will not make up for the energy spent in manufacturing new products. Re-use and recycling are still better like incineration and landfill, energy savings from waste prevention and recycling are likely to be greater than the energy produced.Theagricultural wastes are not fully utilized and some are burnt without energy recovery (Onwualu, 2010).

It has been observed in our localities that the traditional method of disposing palm tree residues by peasant farmers and oil palm processor is by dumping them around their processing centersbecausethere is no awareness or orientation and available technology of processing these residues to useful products like biofuel or chemical feedstock. Henceforth, this disposal method of palm residues was observed in causing environmental pollution (USEPA,2006) such as land, water and air pollution. The palm fruit fibre and other wastes are not easily decomposed and found litter the environment and this has disrupted the landscapes where soil percolation and water infiltration are difficult and result to low crop cultivation. This also creates hidden spaces for insect pest and disease vectorsthat are harmful to rural dwellers. Another observation is that during the raining season, rain erodes some of these residues to nearby water bodies (stream and river) which villagers use for domestic consumption. And some residues obstruct water ways (or flow) and causes flood that affect other cities. Air pollution occurs as the residues are sometimes set ablaze after long period of disposal. The release of gas emission from burning is causing health hazard as inhaled by human and harmful gaseous components of these residues are released to the atmosphere which can cause problem of ozone layer and lead to global warming(UNFCCC 1994).

In view of this, there is need toembark on research development of renewable technology that saves time and it is usually more environmentally friendly, especially on air emissions (Schroeder 2009) which plays vital roles for future energy and chemical supply. In this study, the main objective is to extract the lignocellulosic content of palm fruit fibre and pyrolyseitfor energy (bio-oil) and chemical feedstock productions.

\section{2 .Materials and Methods}

This section describes the sample preparation, renewable technology and proximate analysis of the residue.

\subsection{Sample preparation}

The palm fruitfibreis a waste product of palm kernel fruits after oil processing. The samples was collected from local palm oil processing centre in village near Ogbomoso town $\left(8^{\circ} 07^{\prime} \mathrm{N}, 4^{\circ} 16^{\prime} \mathrm{E}\right)$, Nigeria. The samples used for the study were sun dried and ground into fine particle size. Figure 1, 2, 3 and 4 show the fresh fruits, the palm fruit fibre used, the processing site and residue dump site visited, respectively.

The extraction, pyrolysis and proximate analyses of the samples were carried out at the laboratory of the Department of Chemistry, University of Nairobi, Kenya while ultimate analyses were investigated at the Kenya 
Agricultural and Livestock Research Organization Laboratory. The samples were then screened to give various fractions using different wire mesh sizes. The diameter of the particle size of palm fruit fibre used ranged from 0.250 to $0.550 \mathrm{~mm}$ in form of $0.250,300,0.425$ and $0.550 \mathrm{~mm}$. Each sample was mixed with Sodium Anhydrous in order to make it dried and remove totally the moisture in it.

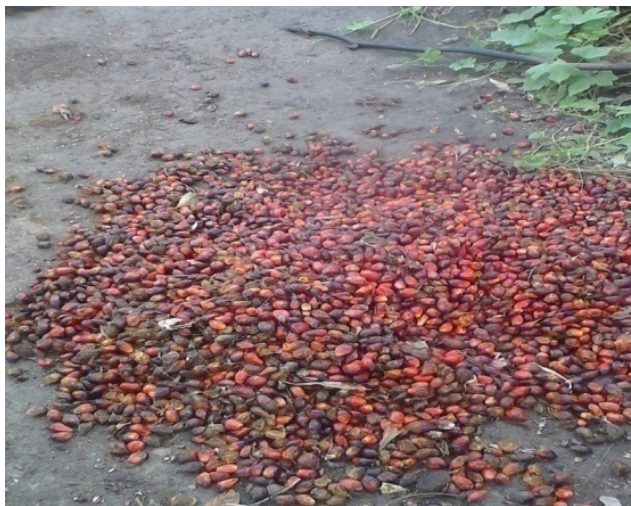

Fig. 1: Fresh palm kernel fruits

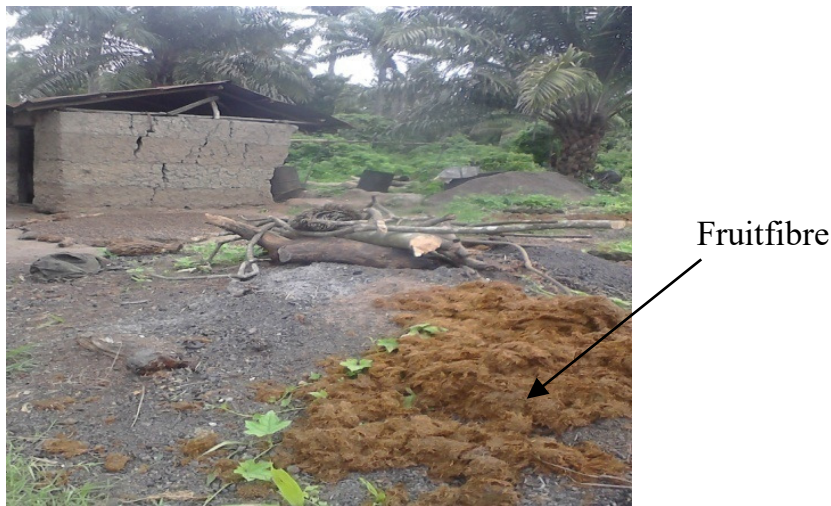

Fig. 2: Palm fruit fibre (residue)

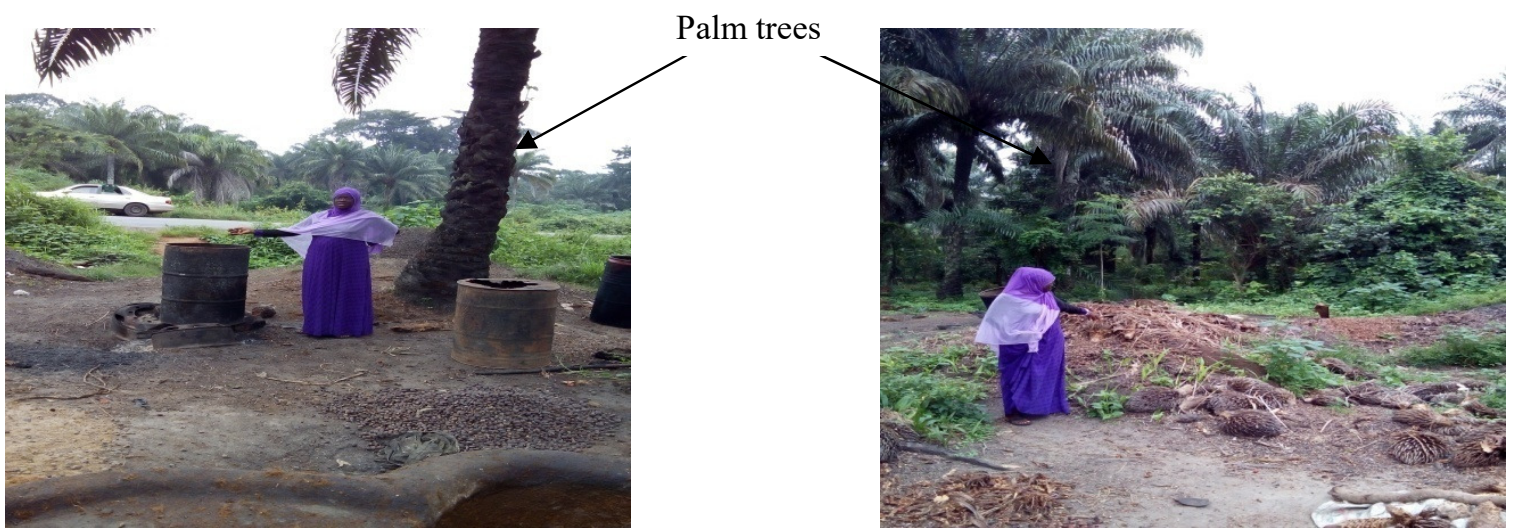

Fig. 3: Oil palm processing site

Fig. 4: Palm tree residues dump site

\subsection{Experimental Procedure}

(a) Extraction or purification of the lignocellulosic material from the samples

Lignocellulose was prepared from palm fruit fibre according to the methods reported by Bello et al. (2009). Fifty (50) grammes of the raw ground palm fruit fibre were measured using an electronic weighing balance Mettla Toledo, with an accuracy of $0.01 \mathrm{~g}$, the sample was put in a $500 \mathrm{ml}$ round bottom flask. Then, $200 \mathrm{ml}$ of ethanol and distill water was measured $(1: 1 \mathrm{v} / \mathrm{v})$ using a $100 \mathrm{ml}$ measuring cylinder, and poured into the sample. The flask containing the sample was put on an electric heating mantle set at $70{ }^{\circ} \mathrm{C}$ and allowed to boil for 30 minutes. Each purification process was maintained for all particle sizes. After the final decantation of the final supernatant, the resultant material (purified sample) was drained and dried in an oven at $105{ }^{\circ} \mathrm{C}$ for $48 \mathrm{~h}$ and cooled in an air tight dessicator with dessicant. This meant extraction or purification of the sample had been achieved to obtain lignocelluloses from the samples.

\section{(b) Pyrolysis Procedure}

The purified samples were pyrolysed in batch-type reactors. Both reactors are the ampoule and the tubular systems. One end-closed narrow cylindrical pyrex tubes of about $3 \mathrm{~cm}$ diameter and $15 \mathrm{~cm}$ long was used. Thepyrex ampoules wasmade by joining bulbs of $5 \mathrm{~cm}$ diameter with the cylindrical tubes. $2 \mathrm{~g}$ of lignocelluloses was weighed in each case and introduced into the reactor by means of narrow plastic funnel. In order to ensure quantitative transfer of the charge, a small Teflon rubber tubing about $2 \mathrm{~cm}$ long was used in the joining of the funnel and reactor outlet, and by gently tapping and varying the amount of the charging materials until the exact weight of $2 \mathrm{~g}$ as required was introduced into the reactor.

A small constriction was made a little above the cellulose level before inserting $0.2 \mathrm{~g}$ of glass wool into the reactor. The wool was held fixed by another constriction above so as to prevent the loss of charge during the evacuation. Pirantvacuum gaugewas used for the evacuation and the glass was sealed with a hand torch burner when the pressure reaches $0.1 \mathrm{mmHg}$. The duration of the evacuation was 5 to 30 minutes for the tubular and 
ampoule reactors. A thermostat oven furnace was required as shown in Figure 7; the isothermal temperature was allowed to run for ten minutes before introducing reactor and was maintained throughout the run. Each pyrolysis reaction lasted for 120 minutes at each temperature selected ranging from 200 to $400{ }^{\circ} \mathrm{C}$. To terminate a run, the reactor was removed from the furnace and allowed to cool to laboratory temperature in a dessicator.

The lignocellulose was pyrolysed and various amount of product of the sample were determined. The buoyancy factor was considered in the evacuation of the gaseous products by subtracting the weight of the air in the ampoules from the weight of the ampoule before ejecting the air inside the ampoule. That of volatile liquid products would be obtained by subtracting the weight of the gaseous product, the weight of the solvent extract and the weight of the unextracted material from the amount charged into the reactor. The solvent extract was obtained by soxhlet extraction as shown in Figure 8, for 72 hours of the liquid solid products of the pyrolysed sample after removing the gases and volatile liquids.

2 grammes of the pyrolysed sample were measured and put into dried thimble container and introducedintosoxhlet extractor. Then $100 \mathrm{ml}$ ofmethanoland dichloromethane solvent, $(1: 1 \mathrm{v} / \mathrm{v})$ eachwaspouredintoa round bottom $(250 \mathrm{ml})$ flask and placed on the electric heating mantle set at $20{ }^{\circ} \mathrm{C}$ for $24 \mathrm{~h}$. Then, the extracted sample wastaken out of the thimble and put into crucible and dried in an oven for 48 hours at a temperature of $105^{\circ} \mathrm{C}$. The extracted solvent in the round bottom flask was then concentrated using the vaccum pump set. The concentrated extract was cleaned using a glass column $(10 \mathrm{~cm})$ filled with sodium sulphate to remove water or impurities. The clean sample filled into $0.2 \mathrm{ml}$ chromatograph vials and then introduced to GC/MS for analysis.

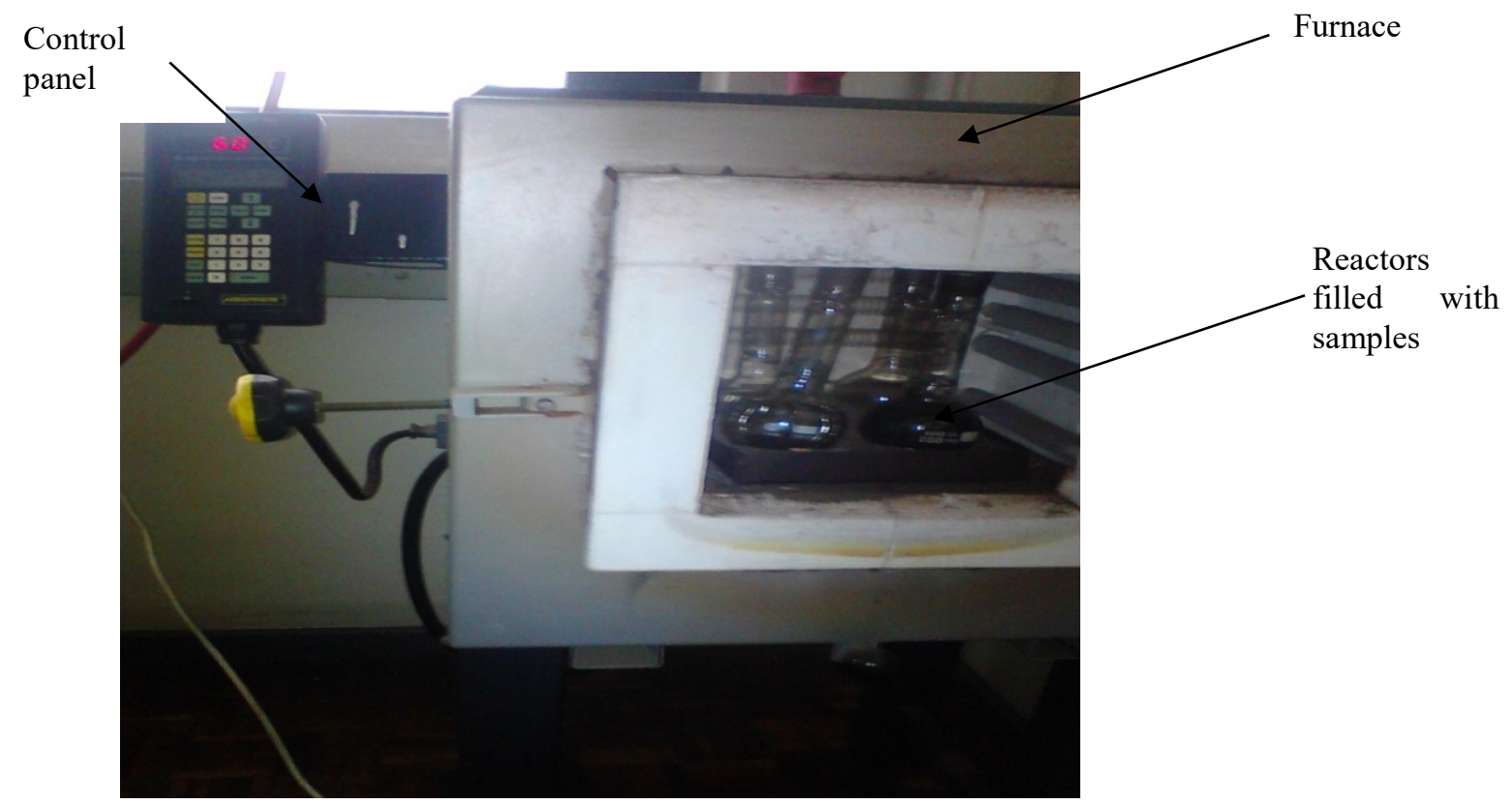

Fig. 7: Pyrolysed samples inside the furnace 


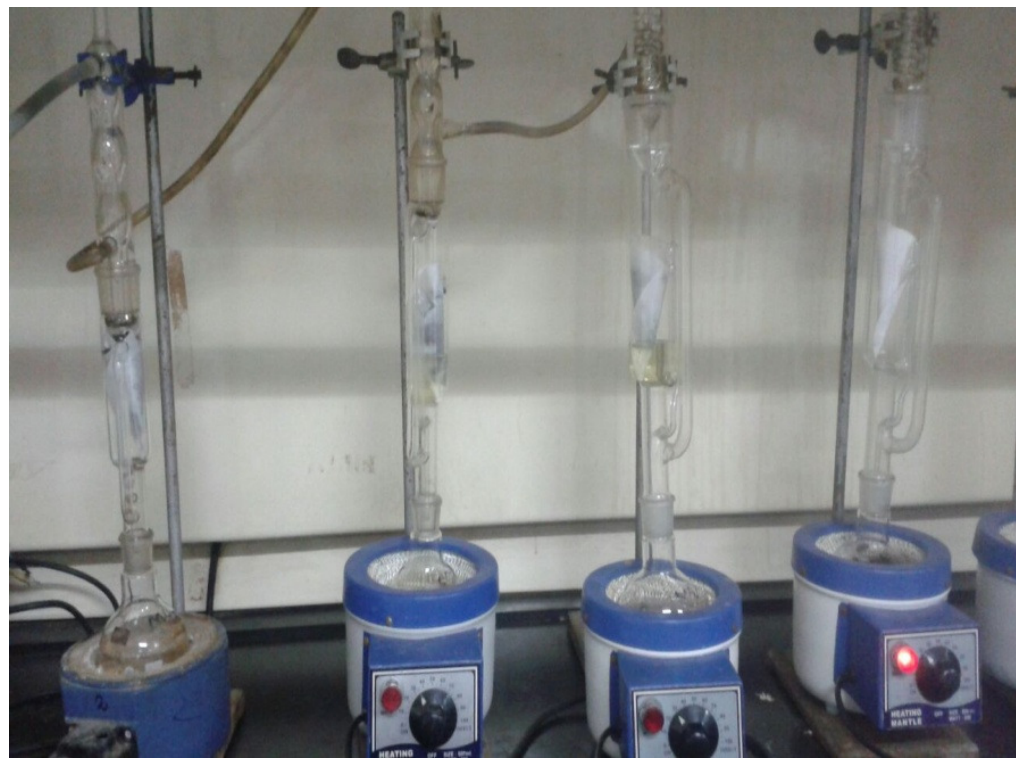

Fig. 8: Soxhlet extractionexperiment for palm fruit fibre

\section{(c) Proximate Analysis}

Proximate composition was carried out in the Department of Physics, University of Nairobi, Kenya. This analysis was commonly determined to investigate agricultural residues as a biomass to develop renewable energy. The sample was analyzed for the volatile matter, ash and fixed carbon contents to determine the fuel property to be obtained (Faizalet al.,2011).

\section{- Determination of the percentage volatile matter content}

The volatile matter content was carried out to determine the fuel property of the dried products. The procedure adopted was in accordance with ASTM Standard D5373-02 (2003). $10 \mathrm{~g}$ of the dried sample was put in crucible and heated in a muffle furnace of model CARBOLITE-ELF $11 / 6 \mathrm{~B}$ at $250^{\circ} \mathrm{C}$ for 7 minutes. The crucible was retrieved and kept to cool in a dessicator to a room temperature of the original weight to obtain the percentage volatile matter content as determined by Fapetu (2000) using equation 4.

$$
\% V_{m}=\frac{100\left(w_{1}-w_{2}\right)}{w_{1}}
$$

where, $\% V m=\%$ volatile matter content, $\mathrm{w}_{1}=$ initial weight of the dried sample, $\mathrm{w}_{2}=$ final weight of the sample after being subjected to $250^{\circ} \mathrm{C}$ for 7 minutes.

\section{- Determination of the ash content}

The ash content experiment was carried out to determine the effect of heat on the dried seeds. This was done in accordance with ASTM Standard D5373-02 (2003). About $10 \mathrm{~g}$ of finely ground sample of physic nut was placed in a crucible and heated in a muffle furnace CARBOLITE-ELF $11 / 6 \mathrm{~B}$ at $250{ }^{\circ} \mathrm{C}$ for $1 \mathrm{~h}$. After cooling it in a desiccator, the final weight was measured. The ratio of the initial weight to the final was expressed as a percentage to obtain the \% ash content of the residue samples using equation 5 as stated by Fapetu (2000).

$$
\% A s h=\frac{100 w_{4}}{w_{3}}
$$

where, $\mathrm{w}_{3}=$ initial weight of the oven-dried sample $(\mathrm{g}), \mathrm{w}_{4}=$ final weight, $\mathrm{g}$.

\section{- Determination of fixed carbon content}

This experiment was carried out to determine the fixed carbon content in the dried seed that would be needed to tackle the growing carbon emissions in the atmosphere with a goal to becoming carbon neutral. The fixed carbon content was obtained by using ASTM Standard D5373-02 (2003),as found by Fapetu (2000). The percentage fixed carbon was deduced from the ash content.

$$
\% F C=100-(\% A s h+V M)
$$

Where $\% \mathrm{C}=$ the $\%$ amount of the fixed carbon, $\% \mathrm{Ash}=\%$ Ash content of dried sample.

\section{(d) Experimental design}

The response surface methodology (RSM) was employed inthis study and this necessary to evaluate the performance of variables in pyrolysis system in other to optimize the bio-oil and biogas in the sample (palm fruit fibre).The effects of tested parameters such as temperatures and particle sizes on the pyrolysis efficiency were determined to identify optimal bio-oil and gas conditions. RSM helps proper design of experimental work and optimization can either be minimum or maximum variables of design parameters. Design expert 6.0 .8 software was used to analyze the tested parameters and response. This was obtained by the response surface regression procedure using the following second-order polynomial equation (Yunardiet al., 2011; Gratuitoet al., 2008; Abnisaet al., 2011).

The temperatures chosen were $200,250,300,350$ and 400 while the particle sizes were $0.25,0.300,0.425$ 
and $0.55 \mathrm{~mm}$ and each experiment was replicated three times. The reaction time and product yield are the responses. The model usedfor predicting is generally a quadratic equation or secondordermodel. The model equation can be expressed as follows;

$$
y=\beta_{0}+\sum_{i=1}^{k} \beta_{i} x_{i}+\sum_{i=1}^{k} \beta_{i i} x_{i}^{2}+\sum \sum_{i<j=1}^{k-1} \beta_{i j} x_{i} x_{j}
$$

Where $\mathrm{y}$ is the predicted response $\left(T_{\text {retention }}, Y_{\text {char }}, Y_{\text {gas }}\right.$ and $\left.Y_{\text {oil }}\right) ; x_{i}$ and $x_{j}$ are the coded independent variables corresponding to temperature and particle size and $\beta_{0}, \beta_{i}, \beta_{i i}$, and $\beta_{i j}$ are intercept, linear, quadratic and interaction constant coefficients respectively. RSM package was also used for regression analysis and analysis of variance (ANOVA). Response surfaces, normal probability and plots were developed using the fitted quadratic polynomial equation obtained from regression, holding one of the independent variables at a constant value corresponding to the stationary point and changing the other variable. The independent variables being studied were temperature and particle size. The dependent variables were the retention time, yields of oil, gas and char. The design of three levels low, medium and high are coded as -1, 0 and +1 was applied to this study. Another step is checking the adequacy of the model and testing of the lack-of-fit which is defined as a measure of a model failure inrepresenting data in the experimental domain (Abnisaet al., 2011).

\section{(e) Characterization of bio-oil}

The bio oil obtained from lignocellulose of palm fibre was used for characterization. Litmus papers blue and red were used to check its acidity and alkalinity. A microprocessor $\mathrm{pH}$ meter (HANNA pH 211) was used to measure the $\mathrm{pH}$ of the oil. Analysis was done at room temperature; the meter was calibrated by measuring $\mathrm{pH}$ of buffer solution to be 7.03 at $23.6{ }^{\circ} \mathrm{C}$. The density of oil was conducted at room temperature of $23.6{ }^{\circ} \mathrm{C}$. The density is defined as sample mass divided by a fixed empty volume of pycnometer. Then a $2 \mathrm{ml}$ pycnometer was used to determine the density, the bio-oil was filled into the flask and weighed the mass. Viscosity of bio-oil was measured using Ostwald Viscometer (a U shape glass viscometer). All experiments were carried out three times and average readings were recorded.

The Fourier Transform Infra-Red spectrometer (IRAffinity-1S, SHIMADZU) was used to characterize the bio-oil produced from palm fruit fibre to produce spectra of different bands of component compounds. Also, GCMS was used to identify the chemical compositions of the bio-oil. The analysis was performed with Angilent HP 6890 (version 4.10) N gas chromatograph equipped with Agilent HP 5075 mass-selective detector (mass spectrometer), using a $30 \mathrm{~m}$ by $0.25 \mathrm{~mm}$ DB-5 ms capillary column $(0.25 \mu \mathrm{m}$ film thickness $)$ with temperature capacity of -60 to $325^{\circ} \mathrm{C}$. The $\mathrm{GC}$ oven was heated to $30{ }^{\circ} \mathrm{C}$ for $3 \mathrm{~min}$ then to $290{ }^{\circ} \mathrm{C}$ at a rate of $3.5^{\circ} \mathrm{C} / \mathrm{min}$ while injection port and detector were set at $300{ }^{\circ} \mathrm{C}$. The carrier gas was helium with flow rate of $28 \mathrm{~cm}^{3} / \mathrm{min}$ and the effluent was monitored using a flame ionization detector (FID). Nitrogen was the makeup gas while Hydrogen and Compressed air are the lightning flame for FID.

A separate constituent of the pyrolysis mixture together with helium carrier gas goes to the flame ionization detector. It was at this zone that the separated organic compounds ionized at a high temperature in contact with hydrogen or air flame. A polarized electric grid captures the resultant ions which generates a current that will be recorded as a chromatogram. Peak areas of individual gases were measured and the abundance was determined from the prepared calibration. The calibration which is an external standardization has a technique involving essentially, the injection of known amounts of pure compounds as reference substance at the same conditions with that of the sample (pyrolytic products). The sample peak was compared with that of the standard. Also, individual compound was identified by matching their elution times along the base line with that of the standard. So, different components in the liquid solvent and their retention time displayed on the screen of the GC-MS monitor.

\section{(f) Energy used in drying the samples}

To determine energy used in pyrolizing the samples, Boltzmann's equation could be used to translate temperature into energy and vice versa. As temperature goes up, so does the kinetic energydo. Energy used in pyrolizing was determined using equation 5:

$$
E=K_{B} T
$$

$\mathrm{E}=$ energy, $\mathrm{J}$

$\mathrm{T}=$ temperature, $\mathrm{K}$

$K_{B}=$ Boltzmann's constant

At Low Temperature $158^{\circ} \mathrm{C}, E=1.38 \times 10^{-23} \times 431 \mathrm{~J}=594.78 \times 10^{-23} \mathrm{~J}$

At high Temperature $442{ }^{\circ} \mathrm{C}, E=1.38 \times 10^{-23} \times 715 \mathrm{~J}=986.7 \times 10^{-23} \mathrm{~J}$

Power dissipated is the amount of energy consumed per time to drying the sample of average weight, $2 \mathrm{~g}$ or it is a measure of how quickly energy is transferred in the system and this was determined using equation 6 :

Time $=2 \mathrm{~h}$

$$
\mathrm{P}=\text { Energy } / \text { time }
$$

At Low Temperature $158^{\circ} \mathrm{C}, \mathrm{P}=594.78 \times 10^{-23} \mathrm{~J} / 3600 \times 2 \mathrm{~s}=8.26 \times 10^{-25} \mathrm{~J} / \mathrm{s}$

At high Temperature $442{ }^{\circ} \mathrm{C}, \quad \mathrm{P}=986.7 \times 10^{-23} \mathrm{~J} / 3600 \times 2 \mathrm{~s}=1.37 \times 10^{-24} \mathrm{~J} / \mathrm{s}$ 


\section{Results and Discussions}

\subsection{Main Properties of palm fibre}

The results of the main properties of the agricultural residue (palm fruit fibre) are presented in Table 1. The proximate analyses are the physical characteristics such as moisture, volatile, ash and fixed carbon contents. The ultimate analysis is the composition of the materials in weight percentage such as carbon, oxygen, nitrogen, magnesium, phosphorus and zinc while the lignocellulosic values are based on the hemicellulose, lignin and cellulose of the materials.

Table 1 presented the main composition of the sample which includes the estimated value for cellulose, lignin and hemicellulose contents. The results revealed that the cellulose, lignin and hemicellulose values of palm fibre are $28.99 \%, 60.36 \%$ and $38.96 \%$, respectively. The respective values of other materials are such that mango pod had 22.96, 50.59, $26.45 \%$ (Olaleye, 2013), wheat straw had 38, 15, $29 \%$ (Hongzhanget al., 2007) while palm shell contained 27.7, 44, $21.6 \%$ (Abnisaet al.,2011), respectively.

From Table 1, the moisture content and dry matter of palm fruit fibre are $5.93 \%$ and $94.09 \%$, respectively. Agricultural residues have different values like that of mango pod is $7.31 \%$ (Olaleye, 2013), coconut shell has $6.0 \%$ (Ojha and Michael, 2006). Several works had been done on proximate analysis of agricultural materials: the value of ash content for mango pod is $2.1 \%$ (Olaleye, 2013); coconut has $0.6 \%$ (Sundaram and Natarajan, 2009); rice straw contains $7.56 \%$ (Ahmad et al., 2011); palm shell has 2.1\% (Abnisaet al.,2011). In this study, the ash content value of palm fibre is $61.30 \%$, this value is higher than that obtained from other materials and it might be because palm fibre is a product of oil crop and high ash content indicates quality energy source and high fuel property (Onifade, 2015).

Moreover, the volatile content of palm fibre is $49.90 \%$ while it was reported that volatile content of rice straw is $66.89 \%$ (Ahmad et al.,2011) while palm shell contains 67.2\% (Ahmad et al.,2011). This indicates that the particles of others are less dense than the former which makes its component to escape into the air. The fixed carbon content of palm fibre is $38.70 \%$. The values reported by other researchers were lower; rice straw contained $14.56 \%$ (Ahmad et al.,2011) and palm shell had 19.7\% (Ahmad et al., 2011).There is higher value of fixed carbon content of physic nut shell, $86.40 \%$. It was observed from previous research that fresh physic nut could absorb more carbon content from the atmosphere i.e more carbon can be emitted with fresh fruits (Onifade, 2015), but burning its residues can do more harm to human because of its high volatility and ability to release gases into the atmosphere. This is one of the most promising solutions for tackling the growing carbon emissions from atmosphere (JWT, 2010), hence reducing the problem of ozone layer. This implies that physic nut has greater potential to absorb carbon emission, thereby making the atmosphere carbon neutral. This factor can be a strategy for climate changeadaptation or mitigation, if more cultivation practice of physic nut is established or encouragedin different countries of the world.

Table 1: Main Properties of the Palm Fruit Fibre

\begin{tabular}{lll}
\hline Property & value & unit \\
\hline Lignocellulosic analysis & & \\
Cellulose & $28.99 \pm 0.029$ & $\%$ \\
Hemi cellulose & $38.96 \pm 0.0897$ & $\%$ \\
Lignin & $60.36 \pm 0.41$ & $\%$ \\
Proximate analysis & & \\
Moisture & 5.93 & $\%$ \\
Dry matter & 94.09 & $\%$ \\
Fat & $20.13 \pm 0.12$ & $\%$ \\
Ash & $61.30 \pm 1.15$ & $\%$ \\
Volatile & $49.89 \pm 3.12$ & $\%$ \\
Fixed carbon & $38.70 \pm 1.15$ & \\
Ultimate analysis & & $\%$ \\
Nitrogen & 1.05 & $\%$ \\
Phosphorus & 0.24 & $\%$ \\
Potassium & 0.29 & $\%$ \\
Calcium & 3.22 & $\mathrm{wt} \%$ \\
Magnesium & 0.08 & $\mathrm{wt} \%$ \\
Iron & 20.17 & $\mathrm{wt} \%$ \\
Copper & 2.17 & $\mathrm{wt} \%$ \\
Manganese & 4.33 & \\
Zinc & 1.83 & $\%$ \\
\hline
\end{tabular}




\subsection{Response Surface Methodology}

Table 2 presented design matrixes and the results obtained from each experiment, twenty (20) experiments were carried with 3 replicates at each level but thirteen (13) experiments were designed based on the number indicated by the statistical software. Temperature and particle size were the parameters selected to study the optimization of pyrolysis process of palm fruit fibre. The experimental design shows the effects of parameters (temperatures and particle size) on pyrolysis responses (the product yield) using a standard of RSM design based on central composite design (CCD) and two-level factorial design which is commonly used to fit a second other model.

Table 3 shows complete results obtained from analysis of variance (ANOVA) using two-level factorial design of Design Expert (6.8) version which includes experimental design and data analysis. It also expressed quadratic models and graphs in form of three-dimensional response surface or probability plot.It also helps to estimate the coefficients in a mathematicalmodel and predict the response.

Table 2: Experimental design matrix and results

\begin{tabular}{|c|c|c|c|c|c|}
\hline \multirow[b]{2}{*}{ Run } & \multicolumn{2}{|c|}{ Actual level of factors } & \multicolumn{3}{|c|}{ Responses } \\
\hline & Temp. ${ }^{\circ} \mathrm{C}$ & Particle size, $\mathrm{mm}$ & Gas, $\mathbf{g}$ & Char, g & Liquid, $\mathrm{g}$ \\
\hline 1 & 300 & 0.55 & 0.413 & 1.59 & 10.758 \\
\hline 2 & 400 & 0.25 & 0.679 & 1.33 & 10.473 \\
\hline 3 & 200 & 0.25 & 0.235 & 1.98 & 9.130 \\
\hline 4 & 300 & 0.42 & 0.499 & 1.51 & 8.273 \\
\hline 5 & 300 & 0.25 & 0.489 & 1.53 & 9.839 \\
\hline 6 & 300 & 0.42 & 0.499 & 1.51 & 8.273 \\
\hline 7 & 200 & 0.55 & 0.044 & 1.97 & 9.023 \\
\hline 8 & 300 & 0.42 & 0.499 & 1.51 & 8.273 \\
\hline 9 & 158.8 & 0.42 & 0.019 & 1.99 & 8.253 \\
\hline 10 & 300 & 0.42 & 0.499 & 1.51 & 8.273 \\
\hline 11 & 300 & 0.42 & 0.499 & 1.51 & 8.273 \\
\hline 12 & 441.42 & 0.42 & 0.994 & 1.03 & 6.657 \\
\hline 13 & 400 & 0.55 & 0.943 & 1.09 & 7.364 \\
\hline
\end{tabular}

Table 3: Analysis of Variance (ANOVA) for various responses

\begin{tabular}{|c|c|c|c|c|c|c|}
\hline Source & Sum of square & Degree of Freedom & Mean Square & F-value & Prob $>F$ & Remarks \\
\hline For Gas Model & 0.98 & 3 & 0.33 & 332.40 & $<0.0001$ & significant \\
\hline A:Temperature & 0.93 & 1 & 0.93 & 944.28 & $<0.0001$ & \\
\hline B:Particle size & $1.486 \mathrm{E}-004$ & 1 & $1.486 \mathrm{E}-004$ & 0.15 & 0.7061 & \\
\hline $\mathrm{AB}$ & 0.052 & 1 & 0.052 & 52.77 & $<0.0001$ & \\
\hline Residual & $8.826 \mathrm{E}-003$ & 9 & 9.807E-004 & & & \\
\hline Lack of Fit & $8.826 \mathrm{E}-003$ & 5 & $1.765 \mathrm{E}-003$ & & & \\
\hline Pure Error & 0.000 & 4 & 0.000 & & & \\
\hline Cor. Total & 0.99 & 12 & & & & \\
\hline$R^{2}=0.9911$ & \multicolumn{2}{|c|}{ Adjusted $R^{2}=0.9881$} & \multicolumn{2}{|c|}{ Predicted $R^{2}=0.9725$} & \multicolumn{2}{|c|}{ Adeq. Precision $=55.398$} \\
\hline For Char Model & 1.05 & 2 & $0.52 \quad 1$ & 106.80 & $<0.0001$ & significant \\
\hline A & 1.04 & 1 & 1.04 & 212.91 & $<0.0001$ & \\
\hline $\mathrm{B}$ & $3.409 \mathrm{E}-003$ & 1 & $3.409 \mathrm{E}-003$ & 0.70 & 0.4235 & \\
\hline Residual & 0.049 & 10 & $4.896 \mathrm{E}-003$ & & & \\
\hline Lack of Fit & 0.049 & 6 & $8.159 \mathrm{E}-003$ & & & \\
\hline Pure Error & 0.000 & 4 & 0.000 & & & \\
\hline Cor. Total & 1.09 & 12 & & & & \\
\hline$R^{2}=0.9553$ & \multicolumn{2}{|c|}{ Adjusted R $\mathrm{R}^{2}=0.9463$} & \multicolumn{2}{|c|}{ Predicted $R^{2}=0.9064$} & \multicolumn{2}{|c|}{ Adeq. Precision $=30.374$} \\
\hline For Liquid model & 12.98 & 5 & 2.60 & 5.96 & 0.0183 & $\overline{\text { significant }}$ \\
\hline A:Temperature & 0.83 & 1 & 0.83 & 1.90 & 0.2105 & \\
\hline B:Particle size & 0.46 & 1 & 0.46 & 1.05 & 0.3388 & \\
\hline $\mathrm{A}^{2}$ & 1.00 & 1 & 1.00 & 2.29 & 0.1738 & \\
\hline $\mathrm{B}^{2}$ & 7.57 & 1 & 7.57 & 17.37 & 0.0042 & \\
\hline $\mathrm{AB}$ & 2.25 & 1 & 2.25 & 5.17 & 0.0571 & \\
\hline Residual & 3.05 & 7 & 0.44 & & & \\
\hline Lack of Fit & 3.05 & 3 & 1.02 & & & \\
\hline Pure Error & 0.000 & 4 & 0.000 & & & \\
\hline Cor. Total & 16.03 & 12 & & & & \\
\hline
\end{tabular}




\section{Effects of Process Parameters on Product Yield}

Fig. 9,10 and 11 presented the effect of temperature and particle size on gas, char and liquid yields of palm fibre. It was observed from Fig. 9 that gas yield increased with increase in temperature but slightly decrease with particle sizes. The increase in temperature leads to formation of more gaseous molecules released, the higher the temperature the higher the gases released to the atmosphere. This means if the residues are burnt in an open space, some will be inhaled by human while some components are released to the atmospherewhichaffects the climate causing global warming (UNFCCC 1994). The gaseous component can also be useful as chemical feedstock in industry (Bello, 2009).

Fig. 10shows the contour graph depicted the effect of process parameters on the char yield. It was observed from the figure that increases in temperature and particle sizes lead to decrease in quantity of char produced. The char has potential soil-quality benefits for farming activities when it is incorporated into the soil. Application of residue char into the soil improves physical and chemical properties of farm land (UNL, 2016).

From Fig. 11, it was observed that as temperature and particle sizes increased, the liquid yield increased to a point of $300^{\circ} \mathrm{C}, 0.55 \mathrm{~mm}$. Fig. 11 shows the contour graph of the effect of the processing parameters on the yield, this reveals the optimum process condition is achieved at $300^{\circ} \mathrm{C}, 0.55 \mathrm{~mm}$. This meant that the bio-oil produced after this point decreased as temperature increased.

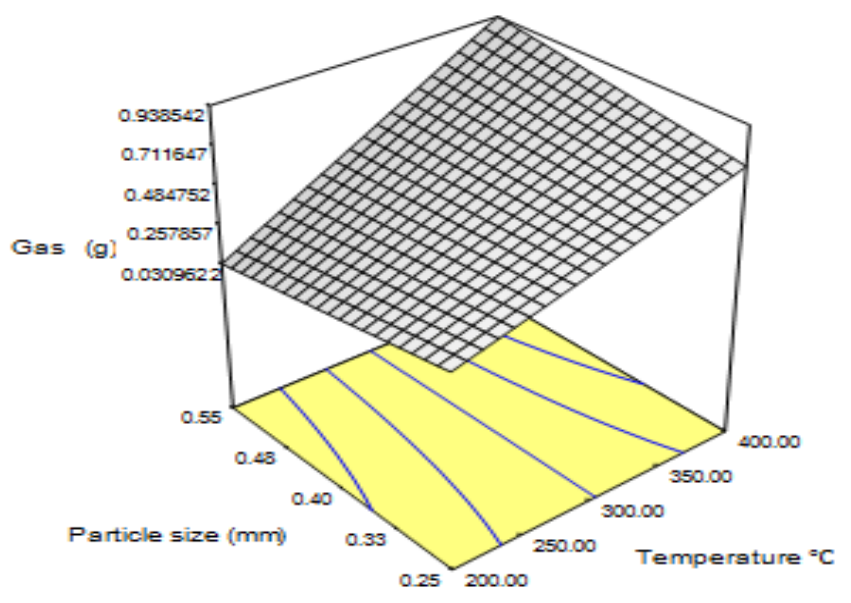

Fig. 9: Effect of Temperature and Particle size on Gas

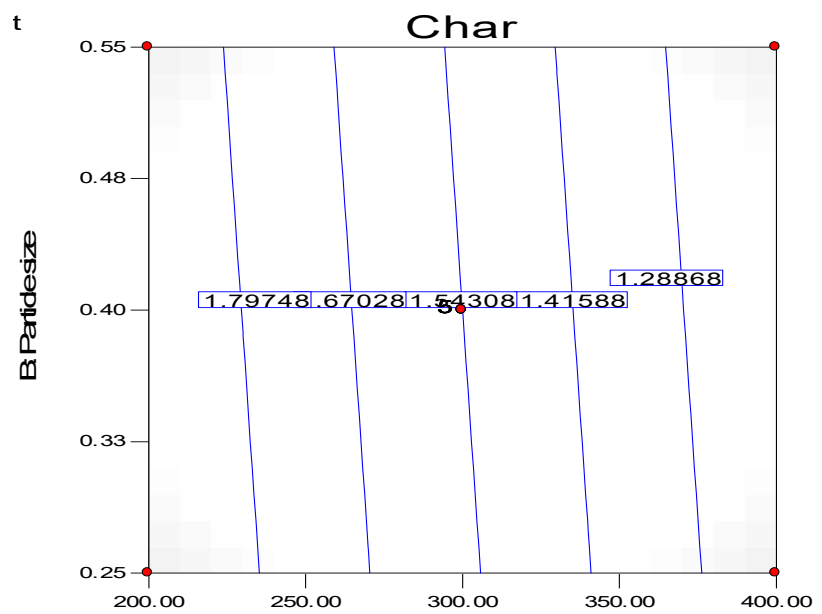

A: Temperature

Fig. 10: Effect of Temperature and Particle size on Char Yield 


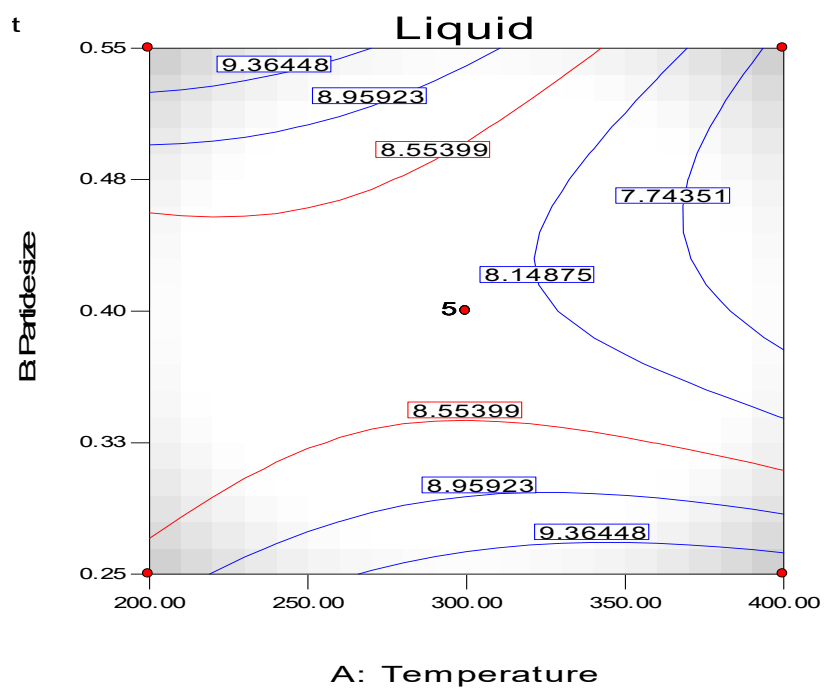

Fig. 11: Effect of Temperature and Particle size on Liquid yield

\subsection{Physical Characterization of Bio-oil}

The physical properties of bio-oil produced from palm fruit fibre are presented in Table 4 . The liquid extracts were acidic in nature because it turned blue litmus paper to red. This indicated that the samples had been burnt under inert condition. The $\mathrm{pH}$ values of oil, whichranged from 4.64 to 6.43 , increased with increase in temperatures, this meant that oil obtained at high temperatures are slightly acidic while oil obtained at low pyrolitictemperatures indicate low $\mathrm{pH}$ readings which is more acidic. The density of the oil is $0.8319 \mathrm{~g} / \mathrm{ml}\left(831.99 \mathrm{~kg} / \mathrm{m}^{3}\right)$ at $23.6{ }^{\circ} \mathrm{C}$. It was observed that all density values at different temperatures and particle sizes gave similar readings. The density and viscosity are related to phenomenon of liquid floatation which can have significant effect on fluid atomizers. The bio-oil produced in this study gave viscosity of $0.695 \mathrm{cPa}$ room temperature; this value was less than that of water used as standard. This indicated that the viscous period of bio-oil is less than that of water. Hence, this could be due to low value of water content (5.93\%)which caused it to be less viscous. The presence of water content in bio-oil shows the presence of lignin in the raw material which is $60.36 \%$. The calorific value of the bio-oil is 22.33 $\mathrm{kJ} / \mathrm{g}$ as shown in Table 4, this shows the amount of energy produced by the complete combustion of $0.291 \mathrm{~g}$ of the oil. The calorific value is an important factor to determine the energy content of the fuel. Compared to other common fuel, gasoline $(47 \mathrm{~kJ} / \mathrm{g})$, Diesel $(45 \mathrm{~kJ} / \mathrm{g})$, Ethanol $(29.7 \mathrm{~kJ} / \mathrm{g})$, wood $(15 \mathrm{~kJ} / \mathrm{g})$ coal $(15 \mathrm{~kJ} / \mathrm{g})$ and natural gas $(54 \mathrm{~kJ} / \mathrm{g}$ ) (NIST), this indicates that bio-oil from palm fruit fibre is a potential source of energy and can be upgrade first before using it as fuel.Fig. 12 presented the bio-oil produced from palm fruit fibre.

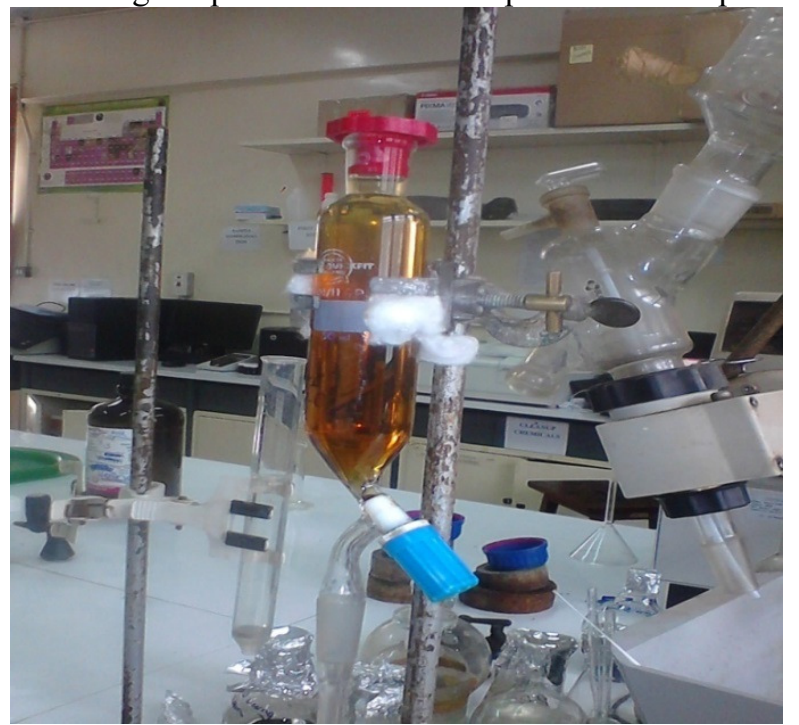

Fig. 12: Bio-oil produced from palm fruit fibre 
Table 4: Physical properties of bio-oil

\begin{tabular}{lll} 
Properties & Value & Unit \\
Viscosity & 0.695 & $\mathrm{cP}$ \\
$\mathrm{pH}$ & $4.64-6.43$ & Acidic \\
Density at $23.6^{\circ} \mathrm{C}$ & 831.99 & $\mathrm{~kg} / \mathrm{m}^{3}$ \\
Calorific value & 22.33 & $\mathrm{~kJ} / \mathrm{g}$ \\
Water content & 5.39 & $\%$ \\
$\mathrm{C}$ & 65.24 & $\%$ \\
$\mathrm{H}$ & 5.07 & $\%$ \\
$\mathrm{~N}$ & 1.10 & $\%$ \\
$\mathrm{O}$ & 28.60 & $\%$ \\
\hline
\end{tabular}

\subsection{Chemical Characterization of Bio-oil}

Fig. 13 presented the results of the spectra obtained from the Fourier Transform Infra-Red spectrometer which was used to characterize the bio-oil produced from palm fruit fibre. The O-H stretching vibrations between 3200 and $3400 \mathrm{~cm}^{-1}$, show the presence of phenols and alcohols. The $\mathrm{C}-\mathrm{H}$ stretching vibrations between 2800 and $3000 \mathrm{~cm}$ ${ }^{-1}$ andC-H deformation vibrations between 1350 and $1450 \mathrm{~cm}^{-1}$ show the presence of alkane groups. The $\mathrm{C}=\mathrm{O}$ stretching vibrations between 1680 and $1750 \mathrm{~cm}^{-1}$ arecompatible with the presence of ketones, quinones,aldehyde groups. The peaks between 1500 and $1645 \mathrm{~cm}^{-1}$ represent $\mathrm{C}=\mathrm{C}$ stretching vibrations, indicated the presence of alkenes. Besides, mono and polycyclic and substituted aromatic groups can be identified by the absorption peaks between $690-900$ and $1350-1450 \mathrm{~cm}^{-1}$. Then, Ethers can be identified by a strong C-O stretching band near 1100 $\mathrm{cm}^{-1}$ due to the C-O-C linkage in the compound. Aromatic ethers show a strong band near $1250 \mathrm{~cm}^{-1}$, while cyclic ethers show a C-O stretching band in the range of 1250-900 $\mathrm{cm} \mathrm{-}^{-1}$. A broad N-H wagging band appears at 750-650 $\mathrm{cm}^{-1}$ represents secondary amides.

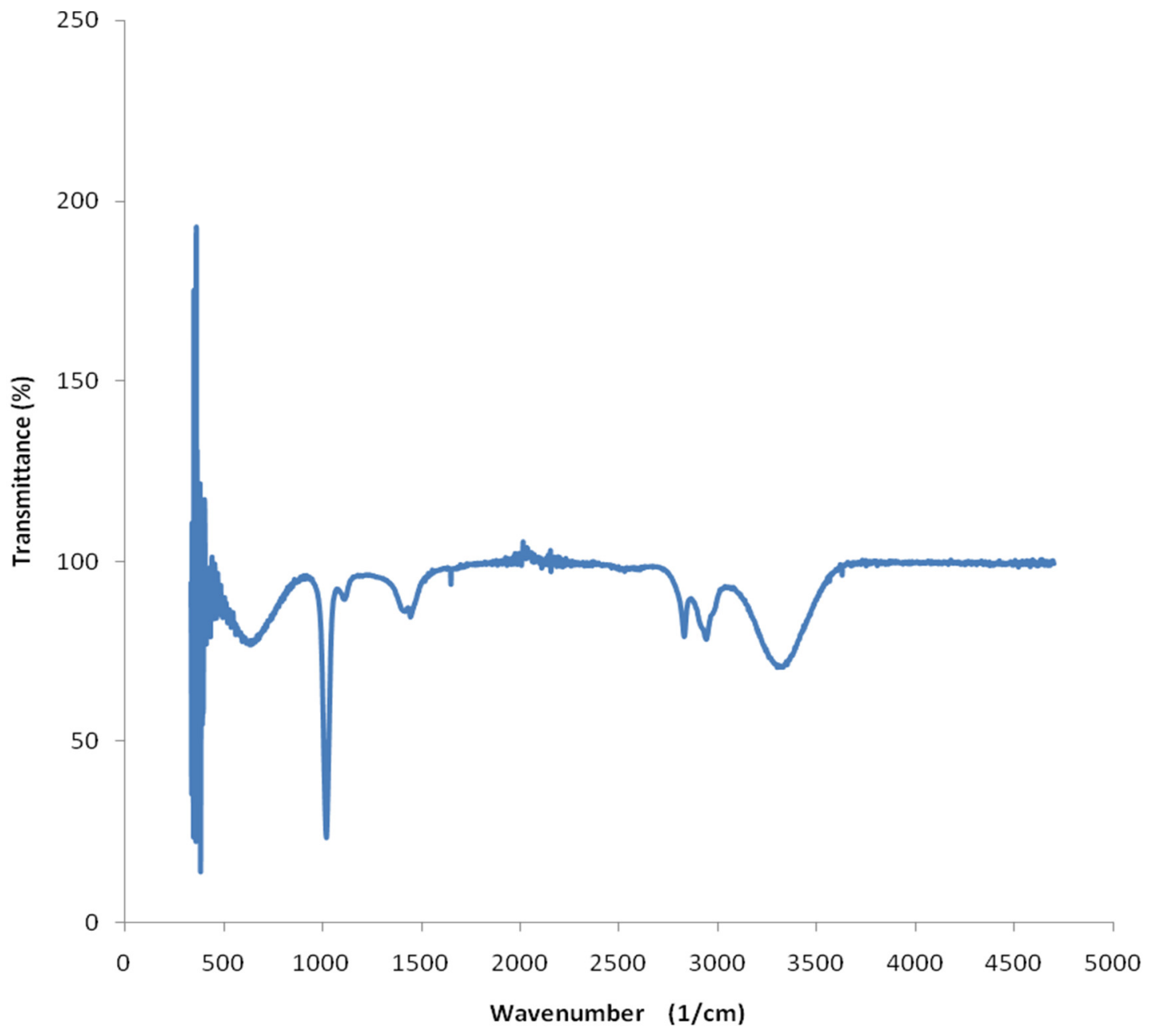

Fig 13: FT-IR spectra bio-oil derived from palm fruit fibre 
Table 5: Identification and quantification of chemical compounds in bio-oil by GC-MS Analysis

Table 6 e Identification and quantification of chemical compounds in bio-oil by.

\begin{tabular}{llcl}
\hline Chemical compounds & $\begin{array}{c}\text { Molecular formula } \\
\text { (g/mol) }\end{array}$ & $\begin{array}{c}\text { Molecular weight } \\
\text { \%o }\end{array}$ & Peak Probabilty \\
\hline 3-methyl Pentadecanoic acid & $\mathrm{C}_{16} \mathrm{H}_{32} \mathrm{O}_{2}$ & 256 & $1.47-2.85$ \\
2,16-methyl Hexadecanoic acid & $\mathrm{C}_{18} \mathrm{H}_{34} \mathrm{O}_{2}$ & 284 & $1.30-10.15$ \\
Methyl Hexadecanoic acid & $\mathrm{C}_{17} \mathrm{H}_{34} \mathrm{O}_{2}$ & 270 & 81.3 \\
14-methylPentadecanoic acid & $\mathrm{C}_{17} \mathrm{H}_{34} \mathrm{O}_{2}$ & 270 & $9.92-28.7$ \\
Tridecanoic acid & $\mathrm{C}_{17} \mathrm{H}_{34} \mathrm{O}_{2}$ & 270 & 2.58 \\
Ethyl Pentadecanoic acid & $\mathrm{C}_{17} \mathrm{H}_{34} \mathrm{O}_{2}$ & 270 & 6.53 \\
EthylEicosanoic acid & $\mathrm{C}_{22} \mathrm{H}_{44} \mathrm{O}_{2}$ & $3.53-11.3$ \\
Ethyl Hexadecanoic acid & $\mathrm{C}_{19} \mathrm{H}_{38} \mathrm{O}_{2}$ & 290 & 2.84 \\
Ethyl Tridecanoate & $\mathrm{C}_{15} \mathrm{H}_{30} \mathrm{O}_{2}$ & 242 & 4.46 \\
MethylOctadecanoic & $\mathrm{C}_{19} \mathrm{H}_{38} \mathrm{O}_{2}$ & 298 & 10.5 \\
16-methyl heptadecanoate & $\mathrm{C}_{19} \mathrm{H}_{38} \mathrm{O}_{2}$ & 298 & 60.7 \\
Ethyl Octadecanoic acid & $\mathrm{C}_{20} \mathrm{H}_{40} \mathrm{O}_{2}$ & 312 & 0.93 \\
Nonadecanoic acid & $\mathrm{C}_{21} \mathrm{H}_{42} \mathrm{O}_{2}$ & 326 & 3.73 \\
Cyclopropanepentanoic & $\mathrm{C}_{20} \mathrm{H}_{38} \mathrm{O}_{2}$ & 310 & $2.7-4.63$ \\
Tetradecanoic & $\mathrm{C}_{16} \mathrm{H}_{32} \mathrm{O}_{2}$ & 256 & 5.48 \\
Ethyl Heptadecanoic & $\mathrm{C}_{19} \mathrm{H}_{38} \mathrm{O}_{2}$ & 298 & $2.71-12.3$ \\
2-2-hydroxyethoxy & $\mathrm{C}_{22} \mathrm{H}_{44} \mathrm{O}_{4}$ & 372 & 49.4 \\
Hexadecanoic acid & $\mathrm{C}_{18} \mathrm{H}_{36} \mathrm{O}_{2}$ & 284 & $7.31-41.0$ \\
Isopropyl palmitate & $\mathrm{C}_{19} \mathrm{H}_{38} \mathrm{O}_{2}$ & 298 & $7.1-14.3$ \\
Ascorbic 2,6-dihexadecanoic & $\mathrm{C}_{38} \mathrm{H}_{68} \mathrm{O}_{8}$ & 652 & 2.8 \\
Ascorbic acid, 6-octadecanoate & $\mathrm{C}_{24} \mathrm{H}_{42} \mathrm{O}_{7}$ & 442 &
\end{tabular}

GC-MS was used to analyze and identify the chemical components in the liquid. Table 5 presents the details results of GC-MS analysis. Themost abundant products and highest peak area achieved by hexadecanoic (81.3\%). Other prominent products are pentadecanoic acid (1.47-14.5\%), octadecanoic (2.6-70.1\%), eicosanoic (3.5$11.3 \%), 2-2$-hydroxyethoxy (2.71-12.3\%), Ascorbic 2,6-dihexadecanoic (7.1-14.3) and Isopropyl palmitate (7.31-41.0). It was observed that different values were obtained at various temperature and particle sizes. This shows effect of experimental parameters (temperature and particles sizes) on the chemical compounds produced from palm fruit fibre. For instance, highest peak of methyl- hexadecanoic, $81.3 \%$ was obtained at $158.8^{\circ} \mathrm{C}, 0.42$ $\mathrm{mm}$, methyl-pentadecanoic acid was high, $14.5 \%$, at $441.42{ }^{\circ} \mathrm{C}, 0.42 \mathrm{~mm}$, eicosanoic had value of $11.3 \%$ at $300{ }^{\circ} \mathrm{C}, 0.25 \mathrm{~mm}$. heptadecanoic has highest peak at $200^{\circ} \mathrm{C}, 0.55 \mathrm{~mm}$. Only $300{ }^{\circ} \mathrm{C} 0.25 \mathrm{~mm}$ and $400{ }^{\circ} \mathrm{C} 0.25 \mathrm{~mm}$ contained Ascorbic 2,6-dihexadecanoic. There are a great number of other compounds but their peak areasare low, so this study did not examine them further. Every compound in Table 5 is classified as aromatic oxygenated and hydrocarbon compounds which are dominant compounds in the palm fruit fibre oil. Oxygenated content is favorable to be used for fuels while other compounds can be useful for chemical productions. The results obtained in this study are different and values are higher than those obtained from palm kernel shell by Faisal et al.(2011).

\section{Conclusion}

The pyrolysis of palm fruit fibre had been examined;experimental factors (temperatures and particle sizes) had significant effect on the bio-oil and chemical compounds yielded from the residues. Investigation was done to determine optimum factors that can maximize bio-oil production by generating mathematical equations from response surface methodology approach. The optimum process condition of bio-oil was produced by $300{ }^{\circ} \mathrm{C}$ and $0.55 \mathrm{~mm}$ while highest peaks were attained at the retention time between 14 and $18 \mathrm{~min}$. Power used in pyrolysing the residuesinside furnace at temperatures 158 and $442{ }^{\circ} \mathrm{C}$ are $4428.26 \times 10^{-25} \mathrm{~J} / \mathrm{sand} 1.37 \times 10^{-24} \mathrm{~J} / \mathrm{s}$, respectively. This paper has outlined how renewable technology is used to breaking agricultural residues and obtains useful products like bio-oil for bio-fuel production and chemicals components for industrial purpose. But their usefulness will provide valuable umbrella terms for the guiding principles of climate change policy.Climate change has become one of the major challenges for mankind and the natural environment. The gas emissions released into the atmosphere in ever rapidly growing volumes are recognized to be responsible for this change (JWT, 2010). It is reflected from the findings that when the residues are burnt, these bio fuels and chemical compounds are released into the atmosphere causing air pollution and resulted to depletion of ozone layer which causes global warming and has negative effects on climate.It is profitable and highly beneficial if energy and chemicals can be produced from residues rather causing environmental pollution.Opportunitiesforsuccess would be enhanced by ensuring a collaborative process which starts at the grassroots (from the rural farmers) to higher educationist and government.

In this framework, climate stewardship becomes apartnership between the public, higher educationist and the government. To implement the findings, it is important that representatives of the relevantstakeholder groups 
separately deliberate on new system of proper disposal of residues and renewable technology in relevant to climate policy. This could then move to symposium and workshops which bring various ideas fromdifferentgroups together to embark on technology that is environmental friendly and use as strategy or policy for climate change.

\section{Acknowledgements}

The authors would like to acknowledge the financial support of the Department of International Development (DfID) and ACU, United Kingdom andtheAfrican Academy of Sciences AAS, Kenya. The research was done at Institute of Climate Change and Adaptation, Nairobi, Kenya.

\section{References}

Abnisa F, Wan Daud W MAandSahuJN (2007)Optimization and characterization studies on bio-oilproduction from palm shell by pyrolysis using responsesurface methodology. Journal of Biomass and Bioenergy, 35: 3604-3616.Available at:http://www.elsevier.com/locate/biombioe

Adejuwon JO, Odekunle TO (2006). Variability and the Severity of the "little Dry Season" in Southwestern Nigeria, America Journal ofMeteorogical Soc.483-493.

Ahmad J U, Saidur R, Masjuki H H, Mekhilef S, Ali M B and Furqon M H (2011) An application of energy and exergy analysis in agricultural sector of Malaysia. Journal of Energy Research, Energy Policy, 39:7922-7929. Available at:onlinelibrary.wiley.com/doi/10.1002/er.1023/fullJohn Wiley \& Sons.

BalatM,Kirtay E and Balat H (2009) "Main routes for the thermo-conversion of biomass into fuels and chemicals. Part 1: Pyrolysis systems." Energy conversion Management 50:3147-3157. Available at:https://books.google.com/books? isbn=111856040X

Babu B V and ChaurasiaA S (2003)Modelling, Simulation and Estimation of Optimum Parameter in Pyrolysis of Biomass.Energy Conversion Management. 44:21352158.https://books.google.com/books?isbn=8126909587

Bello I A, Giwa A A, Bello O S, Oladipo M A and Amuda OS (2009) Study of pyrolysis of lignocellulosic material from mahogany at low temperature and pressure. International Journal of Biological and Physical Sciences. Science Focus, 14 (2):146-154.Available at:https://mail.google.com/mail/u/0/\#inbox

Bridgewater AV (1996) "Production of high grade fuels and chemicals from catalytic pyrolysis of biomass", Catalysis Today,29: 285-295.Available at:https://books.google.com/books? id=owiVwfMGPKcC

BridgewaterAV, ToftA J, and Brammer J G (2002) "A techno-economic comparison of power productionbybiomass fast pyrolysis with gasification and combustion". Renewable and Sustainable Energy Reviews 6: 181-248.Available at:https://eclass.duth.gr/.../Economic\%20c...

Fapetu O P (2000) Production of charcoal from Tropical Biomass for Industrial and Metallurgical Process. Nigeria Journal of Engineering Management, 1(2):34-37.Available at:www.academia.edu/4772640/IJMRA-3543. Glossary - Climate Change, 2001.Arctic Climatology and Meteorology Education Center.

National Snow and Ice Data Center, NSIDC.Glossary, in IPCC TAR WG1 2001, http//nsidc.org/arcticmet/glossary/climate change.html.

Goyal HB, Seal DandSaxena, RC (2006) "Bio-fuels from thermo-chemical conversion of Renewable resources: A review”.IndianInstitute of Petroleum, Dehradun 248005, India.Renewable and Sustainable Energy Reviews 12:
504-517.
Available at:top25.sciencedirect.com/subject/energy/11/...and.../19/\&www.sciencedirect.com/science/.../S18766102 11045103.

Das, P., Sreelatha T. and Anuradda, G. (2004): Bio-oil from Pyrolysis of cashew nut shell characterization and related properties, Journal of Biomass and Bioenergy, 27:265-275.

Demirbas, A. (2007). Fuel Processing Technology,vol. 88 pp. 591-597.

Dermirbas, A. and Arin, G. (2002).An Overview of Biomass Pyrolysis. Journal of Energy Sources. Vol. 24, pp. 471-482.

Faisal, A. Wan Daud, W.M.A. Sahu,J.N. (2007).Optimization and characterization studies on bio-oilproduction from palm shell by pyrolysis using responsesurface methodology. Journal of Biomass and Bioenergy, vol. 35: 3604-3616.

Fapetu, O.P. (2000). Production of charcoal from Tropical Biomass for Indusrial and Metallurrgical Process. Nigeria Journal of Engineering Management Vol. 1 (2):34-37.

Gerrit, B. (2012).Pyros: A new Flash Pyrolysis Technology for the Production of Bio-oil. TNO Science and Industry, P.O.Box 342, 7300 AH Apeldoorn, Netherlands.

Goyal.H.B.; Seal. D.; Saxena, R.C.; (2006); "Bio-fuels from thermo-chemical conversion of renewable resources: A review".Indian Institute of Petroleum, Dehradun 248005, India.Renewable and Sustainable Energy Reviews 12: 504-517.

Hongzhang C and Liying L (2007) Unpolluted Fractionation of wheat straw by steam explosion and Ethanol Extraction.

Bioresource

Technology.

98:666-676.

Available 
at:wenku.baidu.com/view/2e907a52f01dc281e53af048.

JekayinfaSO and Omisakin OO (2005) "The energy potentials ofsome agricultural wastes as local fuel materials in Nigeria". Agricultural Engineering International, the CIGR E-Journals of ScientificResearch and Development, Manuscript EE 05,3:10.Available at: www.cigrjournal.org https://ecommons.cornell.edu/.../EE\%2005\%20003\%20Jekayinfa\%20fin.

Jekayinfa SO and Scholz V (2007) "Assessment of availability and cost of energetically usable crop residues in Nigeria”. Conference on International Agricultural Research for Development,Tropentag,2007.Available at:citeseerx.ist.psu.edu/viewdoc/download?doi=10.1.1.603.3404..

JWT, (2010). Jatropha World Team, Centre for Jatropha Promotion and Biodiesel, Available at info@jatrophaworld.origin@jatrophaworld.org.

NASA, 2011. Global warming and climate change. Available at: http:www.nasa.gov/topics/earth/features/climate_by_any_other_name.html.

Ojha T P and Michael A M (2006) Principles of Agricultural Engineering. Jain Brothers, New Delhi India, vol. 1, pp 205-215. Available at:www.thejainbrothers.com/

Olaleye T O (2013) Pyrolysis of Mango Pod. An unpublished B Tech. dissertation at Department of Agricultural Engineering, LadokeAkintola University of Technology, Ogbomoso, Nigeria. Available at: https://mail.google.com/mail/u/0/\#inbox

Onifade TB, Jekayinfa SO (2015). Application of Response Surface Methodology for Energy Analysis of thin Layer Drying of Physic Nut (Jatropha curcas).J.AgricEng, Global Sci and Technol Forum. 2:1-11.

Onwualu, A.P, (2010): Industrial raw materials from agricultural residues; status, challenges and opportunities. Humboldt Kolleg International Conference, Ogbomoso 11-14 $4^{\text {th }}$, January, 2010. Pp 367.

Osagie OI (2002). Cereal Output to Plunge Next Year, in:AgroBusiness. THISDAY Online.

Ren X, Jinsheng G, Wenliang W, Qiang L, Jianmin C and Ben L (2013)Optimization of Bark Fast Pyrolysis for the Production of Phenol-Rich Bio-Oil.JournalofBioResources8(4):6481-6492.Available at:https://www.researchgate.net/.../273221176 ojs.cnr.ncsu.edu > Home >

Schroeder M (2009) Utilizing the clean development mechanism for the deployment of renewable energies in China. Journal of Applied Energy86:237-42.Available at:https://www.google.com/search?q=econpapers.repec.org/RePEc:eee:appene:v:86:y:2009:i:2:p:237-242.

Sundaram E G and Natarajan E (2009) Pyrolysis of coconut shell: An experimental investigation. The Journal of Engineering Research, 6:(3) 33:39. Available at:tjer.net/site/issue6-2/p4.pd

Tsai W T, Lee M K and Chang Y M (2006) Fast pyrolysis of Rice Husk, Product Yields and Composition, Bioresources Technology, 10:22-28.Available at:https://www.google.com/search? $\mathrm{q}=w w w . n c b i . n l m . n i h . g o v /$

UKEA, 2015. Government Policy and Environmental Agency; climate change and adaptation 2010 to 2015 , Department of Environmental Food and Rural Affairs. https://www.gov.uk/government/policies/adapting-toclimate-change

UNFCCC, 1994."The United Nations Framework Convention on Climate Change". Retrieved in 13 September, 2015. Available at: http://unfccc.int/essential_background/items/1349.php

UNL, (2016) Panhandle Research and Extension Center \& Institute of Agriculture and Natural Resources, University of Nebraska, Lincoln. Available at: www.hpj.com/crops/unl-studying sugar beet chars to improve soil.

USEPA, (2006) United States Environment Protection Agency, Municipal Solid Waste in the United States: 2005 Facts and Figures (EPA A530-R-06011, Office of Solid Waste, US Environmental Protection Agency, Washington DC. Available at: https://www.google.com/search?q=https://www3.epa.gov/epaw.

Van de Velden M, Baeyens J, Brems A, Janssens B andDewil R (2010) "Fundamentals, Kinetics andendothermicity of biomass pyrolysis reaction" Renewable energy 35: 232-242. Available at: https://www.google.com/search?q=wrap.warwick.ac.uk/5562/ https://www.gov.uk/government/policies/adapting-to-climate-change

Yunardi, Zulkifli, Masrianto (2011). Response Surface Methodology Approach to optimizing process variables for densification of rice straw as a rural alternative solid fuel. J. of Applied Sc. 7:1192-1198. 